\title{
The Feature of Female Language in the Novel Love Rosie by Cecelia Ahern
}

\author{
Yushi Aprindah Putri \\ Balikpapan University \\ yushiaprindah@yahoo.com \\ Muhammad Adam \\ Balikpapan University \\ adam@uniba-bpn.ac.id \\ Siti Hafsah \\ Balikpapan University \\ siti.hafsah@uniba-bpn.ac.id
}

\begin{abstract}
:
This journal investigated the feature of female language in the Novel entitled Love Rosie. There are two objectives of this research; 1) to identify type of feature female language used by the main character in the novel Love Rosie and 2) to describe which female language feature support the communication style.The type of research was qualitative descriptive because the data were analyzed and described in the form of words and sentences. The data were taken from the conversations that is uttered by the main character of Love Rosie the novel. The conversation in the novel were taken out as the primary data. The theory used in this research is the sociolinguistics analysis using Robin Lakoff's theory of female language feature and supported by Deborah Tannen's theory of communication styles in women's conversation. The result of the research, the researcher found that the features of female language found in the novel Love Rosie there are eight types, superpolite forms, tag questions, empty adjectives, logical hedges, strong avoidance of words, price color terms, intensifiers, and emphatic stress. The female language feature that is the most widely used main character supports the communication style that tends to use indirect communication styles.
\end{abstract}

Keywords: Female Language, Gender, Sociolinguistics, Communication Style. 


\section{INTRODUCTION}

Sociolinguistics is a branch of linguistics that views or places the position of language in its relationship with the user of the language in society. "Sociolinguistics is the study of the characteristics of language varieties, the characteristics of their functions, and the characteristics of their speakers as these three constantly interact, change and change one another within a speech community" Fishman (1972). Language is one part of sociolinguistics that always takes into account how users in society are influenced by certain social factors. Social factors include: social status, education level, age, economic level, religion, gender, and others. Of all social factors researcher are interested in discussing the influence of language and gender. According to Caplan (1987) asserts that gender is a difference in behavior between men and women other than from biological structures, most of them are formed through processes social and cultural. Gender is related to the process of belief in how male and female should play a role and act in accordance with structured values, social and cultural provisions in their place. In social life gender is very closely related to masculinity and femininity. In social life gender is very closely related to masculinity and femininity.

Female and male have different language term based on their gender. Acording to Tannen (1990) female tend to be more polite and use indirect strategies when they are speaking, while male are less polite and use more direct expressions. This kind of situation cannot be separated from the social judgments and stereotypes formed by the society. People of society build an expectation that female should behave in one way and male in another to be called as an ideal one. When male are expected to be stronger and have more power, female are seen as weak, less powered, and subordinate to male. The existence of those stereotypes, unconsciously, it makes female employ certain characteristics that distinguish them from male.

These special characteristics do not only exist in the level of behavior but also in the level of communication, specifically on the way they use language. That is all fact about language and gender because gender can decide the language. Female are gender who have unique and diverse characteristics Lakoff (1975) says that,"There are ten types of speech features that commonly used by women than men that based on her intuition and observation. Those speech features are lexical hedges fillers, tag question, rising intonation on declaratives, empty adjectives, specialized vocabularies, precise colors terms, intensifiers, hypercorrect grammar, super polite'form, avoidance of strong words, and emphatic stress" (Lakoff, 1975, p.13). and then communication styles can also prove social status, gender, education and can be more sensitive to the people around us and know how to develop our interpersonal relationships with others.Tannen (1990) siad "The differences between the communication styles of men and women go far beyond mere socialization, and appear to be inherent in the basic make up of each sex". The communication style is divided into two direct communication and indirect communication. Direct Communication, Get straight to the point, and easily express the purpose of the conversation. While indirect communication is a style of language that does not show the expression or intent of the actual speaker, seems more polite. In this thesis the author will 
examine the effect of communication style with female language. One of literary works where can study the different feature language gender of male and female and support communication is from the novel titled Love Rosie.

\title{
LITERATURE REVIEW
}

\section{Sociolinguistics}

Sociolinguistics places the position of language in relation to its use in society. This means that sociolinguistics views language as a social system and communication system, and is part of a particular society and culture. Sociolinguistics according to Lakoff (1975) the relationship between language and gender, the theory of the existence of language women that there are some underlying things the emergence of differences between women and men in language. Women and men as humans are part of society, cannot be separated fromsociety.

\section{Language and Gender}

Language and gender is an essential in human life. People need language as a tool to interact with each other, to express their ideas and their feelings. Gender can be defined as the physical and social condition of being male or female. Gender relates to the process of regulating men and women related and in accordance with structured values, social and cultural provisions in which they depend. This is something that humans must do from birth, but this is what it shows. When a baby is born, the status as boy or girl is announced. Gender is a system in which there are only two possibilities system, a person must be a man or woman. Language and gender are interconnected, because gender influences the way a person uses language in social life. Lakoff (1975) said "The relationship between language and gender is the relationship between language and the notion of men and women".There is more evidence kind and style of female language than male, Lakoff said,

\begin{abstract}
"That women's manner of speaking, which is different from men, reflects their subordinate status in society. Thus women's language is marked by powerlessness and tentativeness, expressed through the use of mitigates and inessential qualifiers, which effectively disqualifies women from positions of power and authority" (Lakoff, 1975, p.15).
\end{abstract}

According to Lakoff, female have different languages because humans in the community have vocabulary in English that shows differences in the roles of male and female. Female and male have a different language because their occupations, societies, positions, etc. A female's language shows the power and kind a female. The female manner of speaking can reflect the subordinate status in a society.

\section{Female Language Feature}

Female language indicates the characteristic of female behavior. Female tends to have features in their language compared to male. Recently, many sociolinguistics found that 
male and female have different ways of speaking. They have different features although they speak same language. Female as social group have their own language characteristic whether in spoken or written language. It can be in form of the vocabulary, grammar, pronunciation, etc. Lakoff (1975) mention "That women and men in the language have differences style, male language more assertive, mature and men like to talk openly with the right vocabulary". Instead, the language used by women does not assertive, does not openly (to use the words figuratively), and be careful when presented something, and often using. Words that are gentle and politely or through gestures. Conversely, the language used by women is not strict, not in a manner openly (using figurative words), and be careful when expressing something, and often use more subtle words and polite or through gestures. Its features are as follows:

\section{Lexical Hedges}

Hedge is protected values used by women to protect their words Lakoff (1975) said that hedging is one of the characteristics of language female. This shows a lack of confidence and reflects women's insecurity. Lakoff (1975) says "that hedging is a variation of a feature by which a person can say something a little short to show that something is not entirely so". With hedges, female refer to the frequency of using phrases such as sort of, like, you know, well, kind a, kind of, I guess, and it seems like. The following example shows lexical hedges that used by female:

$\begin{array}{ll}\text { Lo } & \text { : What's that taste like? } \\ \text { April } & \text { : Vodka. } \\ \text { Lou } & \text { : Vodka. Exactly. But I don't want vodka. I } \\ & \text { want vodka and water. And do you wanna } \\ & \text { know why? 'Cause when you're drunk, it tastes } \\ & \text { like vodka. }\end{array}$

The example Lou explained to April. She says "But I don't want vodka. I want vodka and water. And do you wanna know why? 'Cause when you're drunk, it tastes like vodka". Lou wanted April to mix Vodka drinks with Water because according to Lou when people get drunk the water tastes like vodka. Here Lou uses the word "like" with meanings that describe his thoughts about the feeling that water will resemble vodka when drunk, even though the reality is uncertain or doubtful. Based on the sentence Lou used Lexical hedges to protect her confession.

\section{Tag Question}

The tag question is a syntactic device listed by Lakoff which may express uncertainty. There is no syntactic rule in English that only women may use. "But there is at least one rule that a woman will use in more conversational situations than a man. This is the rule of tag question formation" (Lakoff, 1973:53). Tag question is a grammatical structure in which a declarative statement or an imperative is turned into a question by adding an interrogative fragment called the tag. "It is used as a midway between an absolute statement and yes-no question, it is less forceful from the former but more confident than the later" Lakoff (1975, p.15). A woman makes a statement when she believes in her knowledge 
and believes that her statement will be trusted. Like the following sentence: "Sure, it's cold here, isn't it?"

The tag question is used in the case when the speaker and partner know what the correct answer is, and do not require confirmation. Such a situation when the speaker is starting a small conversation, she is also trying to start a conversation with a partner.

3. Rising Intonation on Declaratives

Women also often use high intonation on declarative sentences to show emotion or empathy for something. In addition, according to Lakoff, one of the other female speech characters that often arises is the intonation of 'asking' as an answer when the woman is given a question. This shows the tendency of women who often feel unsure of the questions conveyed to them, or she wants to highlight politeness by turning back to the opponent she said. Here is the example of rising intonation

$$
\begin{array}{ll}
\text { Dephne } & \text { : Like you're above all that. I'm sorry, what? } \\
\text { Rose } & : \text { Uhat is going on? Oh. Sorry. Um, what were you saying? } \\
\text { Dephne } & : \text { I'm trying to hire you for the Met Ball. }
\end{array}
$$

Dephne is talking about planning to choose Rose as her designer during Met Gala, but Rose didn't pay attention to what Daphne was talking about, and it made Dephne upset, and used the rising tone to ask Rose. She said "I'm sorry, what? What is going on?" With an annoying expression.

\section{Empty Adjectives}

Lakoff said that basically limited words for women are not feminine, but indicates inclusion or powerlessness. But there are adjectives that seem to give a limited impression to be used by women only. Some adjectives are neutral (great, neat) and only for women (adorable, charming, sweet, lovely, divine, gorgeous, cute). According to Lakoff (1975) "if a man uses female adjectives, it will damage his reputation". Here is the example: "You look so adorable".

Adorable words in the sentence above are used by women to express their emotional feelings while speaking, this adjective is called an empty adjective which means that the word only concerns emotional reactions rather than specific information. if men who use these women's limited words are often considered feminine and not masculine.

\section{Precise Color Terms}

Women give color details far more precisely in naming colors than men do. This is according to Lakoff (1975) "claims that women use color words like mauve, beige, aquamarine, lavender, and magenta but most men do not". As an example of lexical differences, imagine a man and a woman both looking at the same wall, painted a pinkish shade of purple. The woman may say "The wall is mauve".

6. Intensifiers 
Intensifiers such as so, just, very, and quite indicate more language characteristics of women than men. Lakoff (1975) said "that replacing intensifiers like so for superlatives is absolute (like very, really, utterly) seems to be the best way to involve himself strongly against an opinion, rather than a tag question". Women stop more often without completing the sentence than men, because she started talking without having a plan for what he would say. Look at the following sentence: "I feel so unhappy, that movie made me so sick!"

Men seem to have difficulty using sentences such as this compilation of sentences does not need to be emotional or non-subjective, but women use them.

\section{Hypercorrect Grammar}

Hypercorrect grammar is the use that matches the standard verb form. This includes circumvention of abusive language, apologizing more frequently, and using the most polite forms as additional features. In other words, women speak as much as possible near the Standard English form.

\section{Superpolite Forms}

Lakoff suggests that in the same sense a request might be a very polite order. Who do not require open obedience but suggest something to do as a help or sympathy for speakers. Lakoff (1975) suggests that in the same sense a request might be a very polite order. Women prefer to use Superpolite Forms because "the reason a woman uses language that is more polite than a man in conversation is because a woman is more aware of her status than a man". Lakoff (1975). The following example shows superpolite forms: "Can I get my watch back, please?

Women use the word "please"? To ask for her watch.In the quote above, showing that a woman asks with polite words, "please" the language feature is categorized as a superpolite form. Blatant commands (in an imperative form) express the alleged superior position of the speaker to the speech partner, with his contains his right to enforce compliance. Lakoff (1975:64) said "politeness is developed by societies in order to reduce friction in personal interaction".

\section{Avoidance of Strong Swear Words}

Men and women have preferences for using invective words different. Lakoff (1973: 50) argues that female curses are different from men. Women often use "oh dear" rather than "shit". Women tend to avoid being confused with the basics. Men often use rude and forbidden invective words such as damn, bloody hell and shit often found in male language. While men use strong harsh words, women use more polite versions such as oh dear, my dear, my goodness, goodness and good heavens. Women give a smoother impression in these invective words, far from being rude, dirty and painful. Look at the following sentences:

Oh, dear! You broke my glasses again.

Shit! You broke my glasses again. 
The two types of sentences above are the same in syntactic form and in lexical reference terms. The difference is only in meaningless particle 'meaningless particles' choices. The first sentence will be grouped as female language and the second sentence will be male language.

\section{Emphatic Stress}

Women tend to use words that emphasize speech to strengthen the meaning of speech. Lakoff (1975) said that women use a firm emphasis on increasing their intonation because they anticipate not being taken seriously by their interlocutors. For example, it was a brilliant performance, brilliant 'brilliant' is one example of emphatic stress. This is used to emphasize the meaning of appearance. Women tend to use words which are used to emphasize the utterance or strengthen the meaning of an utterance. For example: It was a brilliant performance.

The word brilliant is one of the examples of an emphatic stress. This word can be used to strengthen the meaning of the utterance.

\section{Communication Style}

Communication style refers to a person's characteristic speaking pattern. It has some features like directness or indirectness, the use of such elements as passive, passiveaggressive, aggressive, and assertive. Men and women tend to employ different communication styles. According to Tanen (1990) Feminine communication is more indirect, elaborate, and emotional, whereas masculine communication is more direct, succinct, and instrumental. Feminine communication is mostly used by women and masculine communication tends to be used by men. Lakoff (1975) also argued that women become unassertive and insecure because they have been taught to speak and act like ladies. Masculine a preference for a goal oriented, assertive and dominant communication style while feminine individuals preferred a supportive, caring and passive communication style. The following is an explanation of the communication style:

\section{Direct Communication}

Direct Communication, get straight to the point, open configuration issues, and express information clearly without the need but guess like transparency. According Tannen (1990) men are being more direct in their conversations although there are some exclusives, they ask less questions, and make a lot of jokes implicating them as some kind of hero, and more concerned with strengthening their status. For example, "please draft and send me the meeting notes tomorrow."

Direct communication is more often used by men because they tend to show firm, to the point, express the true feelings that are felt. Typically find the results to be more aligned with their intent.

\section{Indirect Communication}

Indirect communication focuses on tone and being polite, Avoids direct conflict and bad news, express opinions/concerns diplomatically. According to Tannen (1990) women use 
indirectness in their conversations, asking more questions, women always ask detailed questions about one thing. In addition, women also always use question tags to ensure that what they say gets approval, making less jokes, reflecting emotions and more concerned with intimacy with others during a conversation. Based on the opinion of Tannen women are categorized more often using passive aggressive and passive communication.

For example: "if you get a chance, will you please draft and send me the meeting notes at your convenience?"

Women tend to have an indirect communication style, using softening devices, lexical hedges such as fences and tag questions to soften the impact of their words. This tactic, however, has no sense of firmness and authority. Indirect Communication, Focuses on tone and being polite, Avoids direct conflict and bad news, express opinions, not expresive. The speaker does not explicitly state the intended meaning behind the utterance. It is the hearer's task to analyses the utterance to understand its meaning.

\section{Previous Studies}

To make this research more relevant, then it is necessary to have the previous studies that related to the research. The previous studies of this research as follow:

\section{A Study by Tiara Azhariah Chalida}

The first study is a journal written by Tiara Azhariah Chalida (2016), a student at Andalas University with the title "Features of Woman's language of Song Lyrics Written by Three American Song Writers". The language features of women are the tendency of women to use the language proposed by Robin Lakoff in 1975 in the 'Women language' theory. The purpose of this study It is to see the features women language in fifteen song lyrics from three American song writer entitled; First is Demi Lovato, these are Don't Forget, Heart Attack, La La Land Neon Lights, Nightingale. Second is Adele, these are Need You Now, Rumor Has It, Someone Like You, Right As Rain Painting Pictures. Last is Taylor Swift, these are Dear John, You Belong With Me, The Last Time, Red, Mine. The similarities of her research with this research lies on the Sociolinguistics approach, especially in feature female language. The differences in this research explained that the female language feature can support communication styles used in the main character in the novel, and also the object that will be analyze different from Tiara Azhariah Chalida journal, she use songs.

2. A Study by Rahma Putri Ramadhani

Another researcher is Rahma Putri Ramadhani (2017) from State University of Balikpapan faculty of English Literature. A thesis with title "The Correlation Language and Gender as Woman Language in the Main Character in the Confession of a Shopaholic's Movie. The similarities of her research with this research lies on the Sociolinguistics approach, especially in feature female language.The differences in this research explained the employment of women's language features, to describe the variety of woman's language feature as correlation of language and gender and the researcher would like to describe woman's language correlate to gender in the Confession of Shopaholic movie. While in this 
research explained that the female language feature can support communication styles used in the main character in the novel.

\section{RESEARCH METHODOLOGY}

The type of research used in this study is qualitative research, the basis of qualitative research examines participant perspectives with strategies that are interactive and flexible. This research is called qualitative research since this research presents the descriptive data, in forms of words, spoken or written by people. Qualitative research is aimed at understanding social phenomena from the point of view of participants. According to Moleong (2005) Qualitative research is a research to understand about phenomenon of a subject research, for example: behavior, perception, motivation, attitude, etc. The meaning or understanding of qualitative research is the research used to examine the condition of natural objects where researcher are key instruments.

Qualitative research is descriptive analytic. Data obtained such as observations, interviews, photographs, document analysis, field notes, prepared by researcher in the study sites, not poured in the form and the numbers. Researcher immediately perform data analysis by enriching information, finding relationships, comparing, and findings patterns on the basis of the original data (not transformed in numerical form). The results of data analysis in the form of exposure on the situation under study presented in the form of narrative descriptions. The nature of data exposure generally answers the questions of why and how a phenomenon occurs. For that the researcher is required to understand and master the field of science that examined so as to provide justification about the concepts and meanings contained in the data. In this study the authors use qualitative data research by watching a film adapted from the Love Rosie novel of the same title, reading dialogue in the novel Love Rosie, and reading research about this novel. This way the research was made.

\section{FINDINGS}

\section{The Feature Of Female Language In The Novel Love Rosie By Cecelia Ahern}

The researcher finds eight features of female language in the Rosie Dunne as the main character of the novel Love Rosie. The researcher classification the amount data present of the feature of female language below. 
Prologue: Journal on Language and Literature Vol.6 No.1 (2020)

Diagram 1: The Feature of Female Language

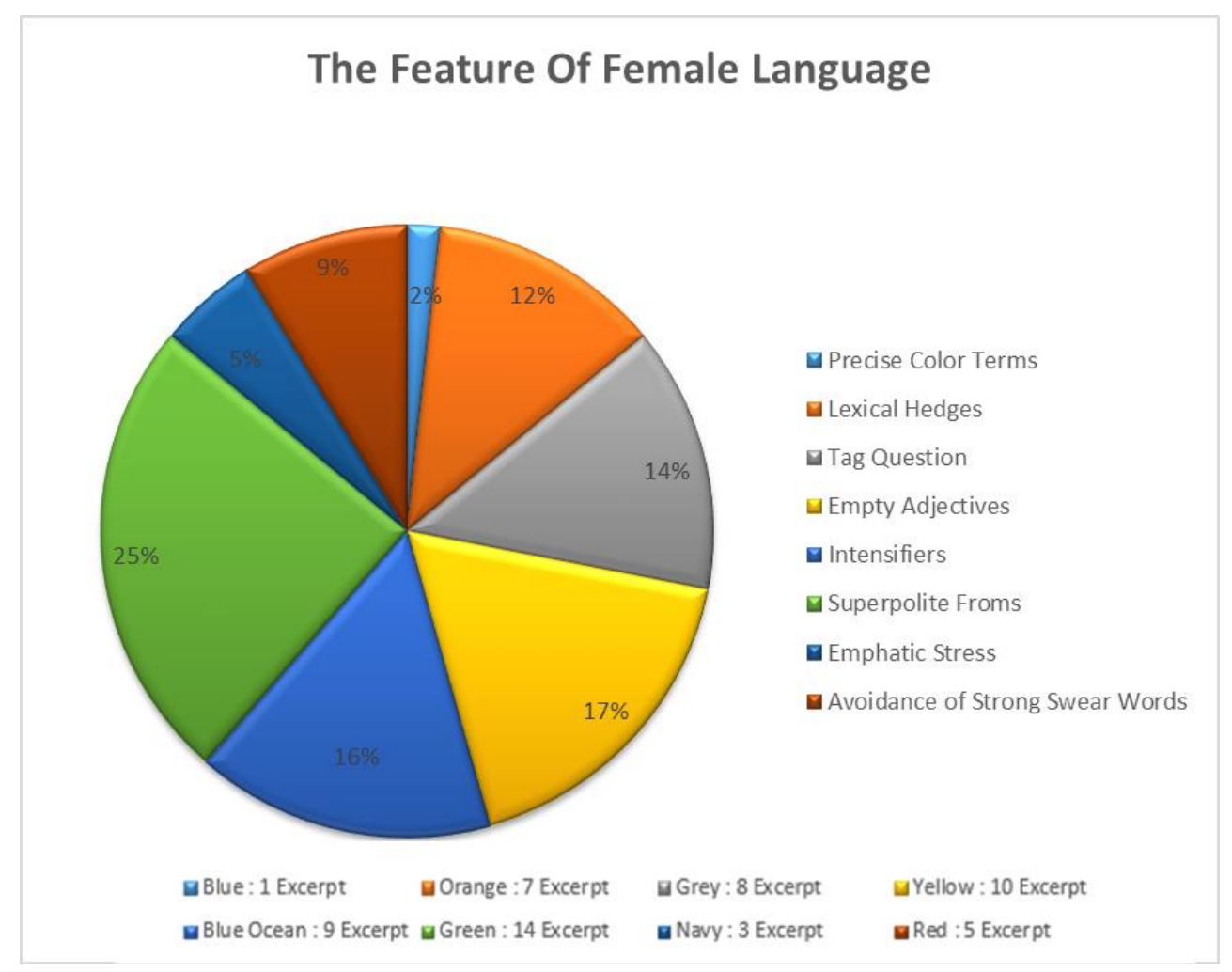

\section{The Feature of Female Language Support Communication Style}

The researcher finds five features of female language support communication style in the Rosie Dunne as the main character of the novel Love Rosie. The researcher classification of amount data present female language support communication style is presented below. 
Prologue: Journal on Language and Literature Vol.6 No.1 (2020)

Diagram 1: The Feature Female Language Support Communication Style

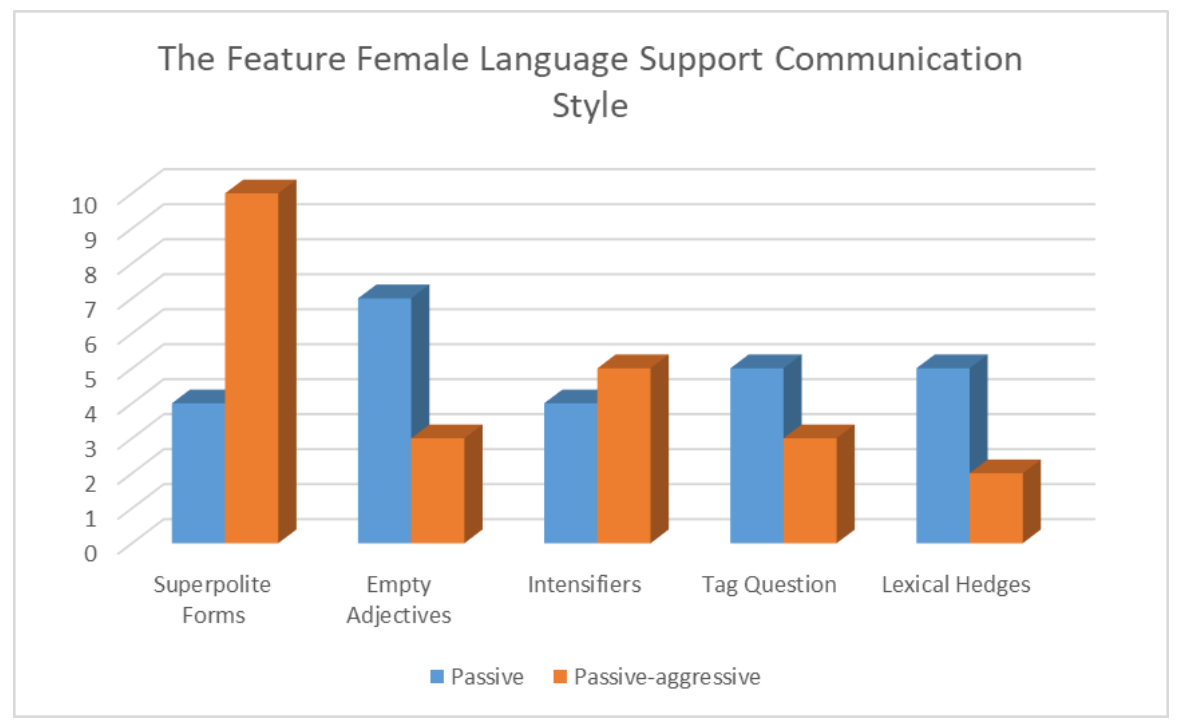

\section{DISCUSSION}

\section{The Feature Of Female Language In The Novel Love Rosie By Cecelia Ahern}

Based on pie chart, the researcher found in the novel of Love Rosie that the main character as a female character has eight language features. The data shown that there are fourteen data related to superpolite forms, ten data related to the empty adjective, nine data related to intensifiers, eight data related to tag question, seven data related to lexical hedges, five data related to voidance of strong swearing words, three data related to emphatic stress and the other one data related to precise color terms. This condition shows the diversity of women's language features in social life based on Lakoff's theory of women's language features. Based on diagram shows the female language features that are often used by Rosie as the main character, the researcher found 5 features: superpolite forms by $25 \%$, Empty adjectives by $17 \%$, intensifiers by $16 \%$, tag questions by $14 \%$, and lexical hedges as much as $12 \%$.

This part discusses the result of data analysis about feature female language and the feature of female language support communication style. Data analysis features female language by Lakoff. Data analysis shows the most female language features used by Rosie. They are a lexical hedge, question tag, intensifier, super polythe form, and empty adjectives. Based on data, it can help researcher discuss the features of the female language support communication style used by Rosie Dunne. Rosie uses indirect communication in her sentences, and it is divided into two styles; passive and passive-aggressive. There are fortyeight data from a total of fifty-seven findings that prove that the female language features used by Rosie support her communication style. 


\section{CONCLUSION}

Based on the results of the research, researcher concludes are the female character in Rosie Dunne use eight features of female language there are lexical hedges,tag question, empty adjective, precise colors terms, intensifiers,super polite form, emphatic stress, and avoiding strong of swearing words. First concludes is the main character mostly use several type of female language feature such as lexical hedge, tag question, and intensifier to show hesitancy, avoid saying definite thing, respond and confirm something, encourage other speaker to participate in talk, strengthen the meaning, and describe emotional state. Then use the superpolite form to show requests politely, empty adjective,precise colors terms , emphatic stress and avoiding strong of swearing words to show women language is more emotional, show her knowledge and evaluative.

The second conclusion is there are to support communication styles for Rosie, can be seen from 48 data that show Rosie's communication style, there are 23 that show passiveaggressive communication style, and there are 25 that show passive communication style. In the feature superpolite form, Rosie uses more passive-aggressive styles because she does not explicitly express her wishes, opinions, feelings to the other person, she is more precise on the surface with polite sentences. In the feature empthy adjectives using indirect communication, she tends to use passive communication style because Rosie uses longwinded and indirect sentences, he also uses a lot of past tense to show information about place or time. In the feature intensifiers uses communication that is almost balanced between passive and passive-aggressive, but the passive-aggressive is the most style she like to used, because even though he uses reinforcement in his opinion, it is only his attempt to reinforce his statement, the sentence he says seems passive but has various meanings that he cannot express. In the feature tag question Rosie uses tag question marks to make sure what she says is true, she also always uses question marks to ensure that what she says gets approval, makes fewer jokes, Rosie's technique of speech tends to be passive because it doesn't have a sense of assertiveness and authority. In the feature lexical hedges Rosie uses the passive style more because she doesn't express her opinion directly, she uses lexical to protect her sentences.

\section{References}

Agustina L. (1995). Sociolinguistic. Jakarta: Rineka Cipta.

Ahren, C. (2004). Love Rosie. Harper Collins Publishers, London.

Aini. L. M. (2016). Women Language Used By The Main Characters Of Mockingjay Movie. Malang : Maulana Malik Ibrahim State Islamic University.

Basow, S.A and Rubenfeld, K. (2003). Effect of Gender and gender. Sex Rules: a Journal of Research.

Caplan, P. (1987). Cultural Construction of Sexuality. London: Tavistock publication.

Chalida, T.A. (2016). Features of Woman's language of Song Lyrics Written by Three American Song Writers. Andalas University. 
Denzin, N. K. 1978. Sociological Methods. New York: McGraw-Hill

Eckert, P. (2003). Language and Gender. United Kingdom: Cambridge University Press.

Fakultas Sastra. (2018) Pedoman Penulisan Skripsi. Balikpapan: Universitas Balikpapan

Forsdale, (1981) Perspectives on Communication. New York: Random House.

Holmes, J. (1992). An Introduction to Sociolinguistics. New York: Addison Wesley Longman Inc.

Lakoff, R. (1975). Language and Women's Place. New York: Harper Colophon.

Moleong, L.J. (2005). Metodologi Penelitian. Bandung: PT Remaja Rosda Karya.

Ramadhani, R.P (2017). The Correlation Language and Gender as Woman Language in the Main Character in the Confession of a Shopaholic's Movie. Balikpapan: Universitas Balikpapan.

Tannen, D. (1990). You Just Don't Understand Woman and Men in Conversation. New York: Morrow. 